DOI: 10.32844/2222-5374-2020-104-2.61

УДК 349.2

Підпала I. B.,

доцент кафедри загальних дисциплін

Медико-природничий університет,

кандидат юридичних наук

\title{
СТРУКТУРНІ ЕЛЕМЕНТИ СОЦІАЛЬНО-ПРАВОВОГО РЕГУЛЮВАННЯ ПРАЦІ МОРЯКІВ
}

Соціальний захист є невід'ємною складовою прав людини, що вимагає приділяти особливу увагу формуванню соціальних стандартів на національному та міжнародному морському ринку праці. На сьогодні радикальні економічні перетворення в Україні, гостро виділили проблему зайнятості працівників морського торгівельного флоту. Істотне скорочення національного флоту, фінансова ситуація, що склалася, в галузі поставили перед моряками України проблему пошуку роботи на світовому ринку. Працевлаштовуючись до іноземного судновласника-роботодавця, моряк «випадає» з правового поля нашої держави і стає абсолютно беззахисним, як з боку нашої держави так і з боку судновласника. Однозначних статистичних даних по кількісному складу морської трудової міграції немає, кількість українських моряків, що працюють за кордоном, оцінюється майже в 60-100 тисяч чоловік. Відсутність можливостей для застосування своїх професійних навиків в Україні є не єдиною насущною проблемою для моряка. Істотним є питання про соціальний захист моряків, що працюють за кордоном, як з боку судновласника-працедавця, так і держави прапора, держави юрисдикції і держави громадянства. З'ясовано, що судновласники при працевлаштуванні моряків поза межами їхньої держави повинні сприяти у збереженні їх грошових заощаджень та допомагати перераховувати заробітну плату їхнім сім'ям, організувавши просту, швидку і надійну систему, яка діяла б за сприяння з боку консулів або інших компетентних органів, капітанів суден, представників судновласників або надійних фінансових установ і давала б змогу морякам, зокрема тим із них, котрі перебувають у іншій країні або служать на судні, зареєстрованому в іншій країні, депонувати чи переказувати свою заробітну плату повністю або частково. Визначено, що на сьогодні національне законодавство України є застарілим. Це полягає насамперед у медичному законодавстві, яке знаходиться у пострадянській системі з недіючими механізмами безкоштовного медичного обслуговування та відсутністю законодавства у сфері обов'язкового медичного страхування. Медичне законодавство України не передбачає спеціальних процедур медичного обслуговування моряків, а наявні механізми $\epsilon$ неефективними.

Ключові слова: соціальний захист, соціально-правове забезпечення, національне законодавство, трудові права моряків, міжнародні конвенції. 
Аналіз останніх досліджень. Слід зазначити, що фундаментальні дослідження з питань соціального захисту моряків, які працюють «під зручним» прапором - відсутні. Зазначене питання розглядається у загальній сукупності регулювання трудових прав моряків такими вченими як: Кокін О.С., Гуцуляк В.Н., Єфимов С.Л., Номоконова О. М. Тому виникає, актуальність в необхідності приєднання України до Конвенції МОП «Про працю у морському судноплавстві» 2006 р. для імплементації сучасних стандартів соціально-правового забезпечення з метою створення надійної національної системи гарантій прав моряків, які працюють під зручним прапором та дієвого механізму їх реалізації.

Виклад основного матеріалу. Соціально - правове забезпечення моряків охоплює в себе принципи: щодо охорони здоров'я, медичного обслуговування, соціально-побутового обслуговування й захисту в морській галузі. Загальні особливості соціального забезпечення регулюється міжнародними актами: Всесвітня декларація прав людини 1948 р., Європейська конвенція про захист прав і основних свобод 1950 р., Міжнародний Пакт про економічні, соціальні та культурні права 1966 р., Європейська соціальна хартія 1961 р., Копенгагенська декларація про соціальний розвиток 1995 р. та й нормами спеціалізованих морських конвенцій МОП: «Про мінімальний вік для роботи в морі» № 7 від 1920 р, «Про трудові договори моряків» № 22 від 1926 р, «Про медичний огляд моряків» № 43 від 1946 р., «Про зобов'язання судновласника у випадку захворювання, травми або смерті моряка» № 55 від 1936 р., «Про страхування моряків на випадок хвороби» № 56 від 1936 р., «Про медичний огляд моряків» № 73 від 1946 р., «Про мінімальні норми в торговельному флоті» № 147 від 1976 р., «Про охорону здоров’я та медичне обслуговування моряків» № 164 від 1987 р., «Про соціальне забезпечення моряків» № 165 від 1992 р., «Про найм і працевлаштування моряків» № 179 від 1996 р. та інші. Загальна кількість морських конвенцій МОП - 36, Україна є учасницею лише 8. Крім того МОП прийняла більше 8 конвенцій, що регулюють загальні питання у сфері праці та соціального захисту і Україна приймає у них участь.

Дані норми мають на меті гарантування моряку захист здоров'я й забезпечення його невідкладного доступу до медичного обслуговування на борту судна й на березі, створення фінансових гарантій для забезпечення моряків від наслідків хвороби, травми або смерті, що відбулися у зв'язку з трудовою діяльністю, забезпечення безпечних та гігієнічних умов праці на борту судна, забезпечення працюючим морякам доступу до берегових об'єктів і служб для догляду за їхнім здоров'ям і благополуччям та вжиття заходів з метою надання морякам доступу до захисту в галузі соціально правового забезпечення [1].

Норми MLC не $\epsilon$ нижчими ніж чинні міжнародні норми у сфері праці та соціального захисту моряків. Як відмітила директор департаменту міжнародних трудових норм МОП пані Клеопатра Думбія-Генрі на трьохсторонньому семінарі, що проходив 7-9 липня 2010 р. у місті Києві «Конвенція МОП «Про працю в морському судноплавстві» 2006 року: рухаючись у напрямку ратифікації та імплементації» : «Мета нової Конвенції полягає в тому, щоб утримати норми чинних конвенцій про працю в морському судноплавстві на нинішньому рівні, залишаючи, разом з тим, кожній країні 
більшу свободу дій у розроблені власних національних законів, що встановлюють вищий рівень захисту» [2].

Національне законодавство носить більш загальний характер правових актів, які можуть застосовуватися до робітників морської галузі: Конституція України, Кодекс законів про працю України, Основи законодавства України про охорону здоров'я, Кодекс торгівельного мореплавства (стосується виключно моряків), Закон України «Про охорону праці» від 14 жовтня 1992 р., Закон України «Про розмір внесків на деякі види загальнообов'язкового державного соціального страхування» від 11 січня 2001 р., Закон України «Про загальнообов'язкове державне соціальне страхування від нещасного випадку на виробництві та професійного захворювання, які спричинили втрату працездатності» від 23 вересня 1999 р., Розпорядження Президента України «Про заходи щодо вдосконалення системи загальнообов'язкового державного соціального страхування» від 11 липня 2005 р., Постанова Кабінету Міністрів України «Про затвердження Порядку здійснення державного нагляду у сфері загальнообов'язкового державного соціального страхування від нещасного випадку на виробництві та професійного захворювання, які спричинили втрату працездатності» від 26 листопада 2003 р.

Існує декілька профільних актів, що діють з часів СРСР: Наказ Мінпромфлоту СРСР «Про затвердження Правил техніки безпеки на суднах морського флоту» від 1976 р., Наказ Мінпромфлоту СРСР «Про затвердження Правил техніки безпеки при виконанні робіт на суднах портового і службово-допоміжного флоту» від 01.08.77 р., Наказ Мінпромфлоту СРСР «Про затвердження Єдиних правил безпеки перевезення вантажів і пасажирів на морських суднах Міннафтопрому» від 20.03 .89 р; Наказ Мінпромфлоту СРСР «Про затвердження Типових галузевих норм безплатної видачі спецодягу, спецвзуття та інших засобів індивідуального захисту робітникам і службовцям морського транспорту» від 24.06 .80 р.

Вирішення конкретних питань соціально - правового забезпечення моряків здійснюється за допомогою локальних нормативних актів (галузева угода, колективний договір). У нашій країні прописані питання соціально - правового забезпечення між судновласником та моряками у Галузевій угоді між Міністерством інфраструктури України і Профспілкою робітників морського транспорту [3].

На сьогодні національне законодавство України є застарілим. Це полягає насамперед у медичному законодавстві, яке знаходиться у пострадянській системі з недіючими механізмами безкоштовного медичного обслуговування та відсутністю законодавства у сфері обов'язкового медичного страхування. Медичне законодавство України не передбачає спеціальних процедур медичного обслуговування моряків, а наявні механізми є неефективними.

3 наведеного вбачається, що національне соціальне законодавство України потребує запровадження у цій сфері механізмів обов'язкового страхування, внески у яке мають робити судновласники або судновласники спільно із моряками, відносно морської галузі, при цьому страхування осіб, що працюють за кордоном теж повинно бути передбачено. Національний роботодавець у встановлених механізмах страхування фактично 
позбавлений реальної можливості ухилитися від матеріальної відповідальності перед моряками, а гарантії держави у цій сфері є гармонічними до Конвенції MLC і КTM України у цілому відповідає вимогам цієї Конвенції, але не відповідає у повному обсязі національному соціальному законодавству, так як не передбачає обов'язкового страхування, а Міжнародні конвенції у цій сфері не ратифіковані Україною. Тож приєднання України до MLC буде тягнути за собою необхідність перегляду вітчизняного законодавства щодо відповідності сучасним морським стандартам. Водночас необхідно приведення у відповідність поточної адміністративної практики Міністерства інфраструктури, М03, Державного комітету України з промислової безпеки, охорони праці та гірничого нагляду, Державної прикордонної служби та Міністерства праці та соціальної політики з цих питань.

MLC кореспондує з Конвенцією МОП «Про соціально-побутове обслуговування моряків на морі і в порту» № 163, 1987 р. та відповідає КТМ України (ст. ст. 73, 76), Постанові Головного державного санітарного лікаря України «Про затвердження Державних санітарних правил та норм для морських та річкових портів» № 46 від 1 грудня 1999 р., Закону України „Про державний кордон України” від 4 листопада 1991 р. (ст. 9, 14), п. „є” ст. 20 «Правил в'їзду іноземців та осіб без громадянства в Україну, їх виїзду з України і транзитного проїзду через її територію», схвалені постановою Кабінету Міністрів України № 1074 від 29 грудня 1995 р.; п. 1.3 «Інструкції про порядок реєстрації іноземців та їх паспортних документів у пунктах пропуску через державний кордон», схваленої наказом Державного комітету у справах охорони державного кордону України № 773 від 24 грудня 2001 p. [4].

Національне законодавство України про державний кордон, міграцію та морський транспорт не передбачає на сьогодні спеціальної процедури доступу моряків (зокрема, громадян України) до берегових об'єктів соціально-побутового призначення, тому є необхідність доповнення КТМ України ст. 55-2 «Доступ моряків до берегових об’єктів соціально- побутового призначення» із дотриманням вимог MLC. Необхідним $є$ передбачення цих вимог у Зводах звичаїв та обов'язкових постановах порту, зокрема шляхом видання сумісного наказу Міністерства інфраструктури, М03, Державної прикордонної служби України та Міністерства праці і соціальної політики, із затвердженням Типового порядку доступу екіпажів суден до берегових об'єктів соціально-побутового призначення. Так як, передбачений допуск моряків, що не $\epsilon$ громадянами України, на ії територію законодавством не гарантовано їм можливість користування об'єктами соціально-побутового призначення. Тому, що сходження осіб, які входять до складу екіпажів іноземних суден на берег дозволяється представником Державної прикордонної служби відповідно до положень Обов'язкових постанов щодо морського (річкового) порту. Але, перелік відкритих для заходження іноземних невійськових суден рейдів і портів, порядок сполучення суден з берегом, сходу на берег членів екіпажу судна та інші відповідні правила встановлюються законодавством України. Спеціалізовані нормативні акти, які б враховували специфіку роботи моряків під іноземним прапором відсутні. Вирішення проблемного питання повинно 
вирішуватися шляхом укладення двосторонніх угод між Україною та державами, які надають право плавання під своїм прапором та державами, які ратифікували або готуються до ратифікації Конвенції 2006 р. MLC [5].

Сьогодні в практиці, як українського мореплавства, так і зарубіжного, становище по додержанню права моряків на щорічну оплатну відпустку склалося несприятливе. Вчасності, згідно опитування організації по вивченню суспільної думки MORI, проведеному серед 6000 моряків із 93 країн світу, 50\% моряків на суднах під «вигідним» прапором не отримують щорічної оплатної відпустки, а на суднах під національним прапором - 37\%. Такому положенню сприяє перехід на строкові контракти, що укладаються на один чи декілька рейсів, коли моряки, відпрацювавши 6-9 місяців, звільняються із компанії в зв'язку з закінченням строку дії трудового договору, а після невеликого періоду відпочинку знову наймаються в ту ж компанію. В трудових договорах, що укладаються, взагалі відсутнє положення про компенсації за невикористані відпустки.

У разі загибелі моряка під час його роботи, включаючи смерть під час дороги на судно чи з судна, або в результаті нещасних випадків на морі або інших, судновласник зобов'язаний виплатити його вдові суму в 60.000 (шістдесят тисяч) доларів США і 15.000 (п'ятнадцять тисяч) доларів США кожній дитині на утримання, яка не досягла 21 року. Якщо у моряка нема вдови названа сума повинна бути виплачена фізичній чи юридичній особі, відповідно до законодавства або іншим чином наділеному правом розпоряджатися спадком моряка, але на сьогодні багато судновласників не виконують свої зобов'язання.

Моряку, постраждалому від нещасного випадку, що стався в період його найму з якої б то не було причини і незалежно від того, чи винен він сам в нещасному випадку, і включаючи нещасні випадки, які сталися під час його прямування на судно чи з судна, і внаслідок якого його працездатність знижена, судновласник повинен виплачувати, додаткову компенсацію через хворобу. Компенсація, за виплату якої судновласник, менеджер, крюінговий агент і інші юридичні особи, в достатній мірі пов'язані з судном, несуть колективну та особисту відповідальність, повинні її призначати за узгодженим медичним висновком, при цьому маючи право, організувати незалежне медичне обстеження, а в разі розбіжностей Профспілка може призначити третіх лікарів, висновок яких буде обов'язковим для всіх зацікавлених сторін. Даний медичний висновок визначить ступінь інвалідності, та встановить розмір компенсації за неї [6].

Для уникнення порушення соціальних прав моряків держави - члени МОП повинні зобов'язувати судновласників дотримуватися принаймні трьох із таких видів соціального забезпечення: медична допомога, допомога у випадку хвороби, допомога по безробіттю, допомога по старості, допомога у випадку виробничої травми або професійного захворювання, сімейна допомога, допомога по інвалідності, допомога у разі втрати годувальника. Морякам - працівникам на суші, надаються права в галузі соціального забезпечення не менші, ніж на морі, з кожного зазначеного виду соціального забезпечення. Для збереження прав у процесі їх набуття особою, на яку вже не поширюється система обов'язкового соціального забезпечення для моряків, а поширюється аналогічна система для працівників, 
які працюють на суші, або навпаки, вживаються заходи щодо координації між відповідними системами [7].

Згідно міжнародних норм судновласник зобов'язаний забезпечувати морякам, стан здоров'я яких потребує медичної допомоги під час їхнього перебування на борту судна, потрібну і достатню медичну допомогу аж до їхнього одужання або до їхньої репатріації, залежно від того, що настане раніше, або тим, котрі залишені за станом здоров'я на території будь - якої держави, харчування і житло до того моменту, коли вони стають спроможними отримати відповідну роботу або репатріацію у разі необхідності.

Моряки, залишені на березі за станом їхнього здоров'я на території будь-якої держави, зберігають за собою право на отримання повної заробітної плати без преміальних виплат з моменту списання їх на берег і до моменту отримання відповідної роботи або до репатріації чи закінчення терміну медичного обслуговування, тривалість якого становить не менш як 12 тижнів. Обов'язок судновласника виплачувати заробітну плату припиниться з того моменту, коли моряки отримують право на грошову допомогу згідно з законодавством держави моряка.

Репатрійовані або списані на берег за станом здоров'я моряки, зберігають право на отримання повної заробітної плати за винятком преміальних виплат з моменту репатріації або списання на берег до моменту одужання або до закінчення терміну медичного обслуговування чи коли моряк отримає право на грошову допомогу. Міжнародні правила застосовуються судновласником у відповідних випадках, ще й до утриманців і осіб, котрі втратили годувальника, стосовно будь-якого виду соціальноправового забезпечення, що застосовується до моряків.

3 метою запобігання конфліктам законів та небажаним наслідкам, які можуть виникнути через відсутність соціального забезпечення або внаслідок непотрібного дублювання відрахувань чи інших виплат та різних видів допомоги, законодавство, що застосовується до моряків, може охоплюватися законодавством тільки одної країни (члена МОП) або законодавством країни під прапором якого плаває судно чи на території якої проживає моряк, а також за взаємною домовленістю між членами МОП можуть встановлюватися в інтересах відповідних осіб правила стосовно законодавства, яке буде застосовуватися до моряків [8].

Моряки, які підпадають під дію законодавства члена МОП, будучи громадянами іншого члена МОП або біженцями чи особами без громадянства, що проживають на території будь-якого члена Організації, мають ті самі права й обов'язки за цим законодавством, як щодо їх охоплення, так і щодо права на отримання допомоги, що й громадяни першого члена МОП. Це також, стосується й права на отримання допомоги моряків утриманцями і особами, які втратили годувальника, незалежно від їхньої національності.

Виплата видів допомоги, не основаних на внесках, може бути поставлена в залежність від проживання одержувача на території країни - члена МОП це стосується і допомоги на випадок втрати годувальника, яка може бути поставлена в залежність від того, чи проживав там померлий годувальник протягом якогось терміну, котрий не може перевищувати: 
а) шести місяців, які передують поданню заяви на отримання допомоги по безробіттю;

b) п’яти років, які передують поданню заяви на отримання допомоги по інвалідності або безпосередньо передують настанню смерті; с) десяти років у віці між 18 роками та пенсійним віком, при цьому може ставитися вимога, щоб з них п'ять років безпосередньо передували поданню заяви для отримання пенсії по старості.

Міжнародні закони і регламенти пов'язані з відповідальністю судновласника, гарантують морякам рівні права, щодо соціально - правового забезпечення, незалежно від місця проживання. Програми збереження прав у процесі набуття, забезпечують морякам, у міру потреби, сумарне обчислення тривалості періодів страхування, зайнятості або проживання, залежно від обставин, згідно із відповідним законодавством.

Програми визначають формулу виплат допомоги по інвалідності, старості, втраті годувальника, у разі потреби, розподілу витрат на відповідне фінансування.

Грошові допомоги по інвалідності, старості та у випадку втрати годувальника, пенсії у випадку виробничої травми і допомоги у випадку смерті, будуть виплачуватися, якщо моряк працював за кордоном, одержувачам, котрі $\epsilon$ громадянами країни - члена МОП або біженцями чи особами без громадянства, незалежно від місця їхнього проживання, відповідно до заходів, яких вживають, у разі потреби, за домовленістю між зацікавленими державами.

Міжнародні програми закликають держави брати участь у збережені прав моряків, набутих відповідно до їхнього законодавства, стосовно таких видів соціального забезпечення, як: медична допомога, допомога у випадку хвороби, допомога по безробіттю, допомога у випадку виробничої травми або професійного захворювання, за винятком пенсій та допомоги у випадку смерті, сімейної допомоги. Ці програми гарантують виплату цих видів допомоги особам, котрі проживають постійно або тимчасово на території країни - члена МОП. Моряк має право на оскарження у разі відмови у наданні допомоги або у разі спору про їі характер, рівень, розмір чи якість, якщо держава у якій він працює не є членом МОП. При цьому, Україні було б доцільно ратифікувати конвенції про соціальний захист моряків, так як вони є суттєво важливими для їх життя [1].

Судновласники повинні забезпечувати належним соціально- побутовим обслуговуванням моряків, як у порту, так і на борту судна та захистом під час виконання ними своїх професійних обов'язків. Ці заходи, повинні враховувати особливі потреби моряків під час їхнього перебування в іноземних державах та при входженні до зон військових дій, у тому, що стосується безпеки праці, охорони здоров'я і організації дозвілля. Соціально-побутове обслуговування, яке надається на борту повинно бути доступним для всіх моряків, незалежно від їхньої національності, раси, кольору шкіри, статі, віросповідання, політичних переконань або соціального походження, а також незалежно від держави реєстрації судна, на якому вони служать.

МФС сумісно з МОП повинні контролювати судновласників у сфері соціально-побутового обслуговування моряків у морі та в порту. При цьо- 
му надавати судновласникам консультації спрямовані на вдосконалення соціально-побутового обслуговування як у порту, так і на борту судна; пропонувати їм укладати угоди: «Про об'єднання засобів» і «Про спільне надання соціально-побутового обслуговування у головних портах», щоб уникнути непотрібного дублювання; заохочувати моряків до участі в спортивних заходах та сприяти в організації міжнародних спортивних змаганнях та міжнародних семінарах з питань їх соціально - побутового обслуговування.

Судновласники повинні забезпечувати надання такого соціальнопобутового обслуговування морякам, яке вимагає країна порту. Соціально - побутове обслуговування моряків повинно забезпечуватися, крім судновласників, відповідно до колективних договорів ще й державою, а також добровільними організаціями. В свою чергу державні органи повинні проводити часті перевірки діяльності в галузі соціально-правового забезпечення моряків, щоб воно відповідало потребам, які змінюються разом з технічними, виробничими та іншими змінами в судноплавстві та залучати в цю діяльність на постійній основі технічно компетентних осіб. Згідно цього доцільно було б створювати державні управління з питань соціально-побутового обслуговування портів, на регіональному та національному рівнях, які б контролювали за діяльністю портових соціальнопобутових служб та консультували осіб, відповідальних за соціально- побутове обслуговування, а також сприяли забезпеченню координації між цими особами. Фінансування соціально-побутового обслуговування моряків повинно забезпечуватися регулярно за допомогою виплат 3 державних фондів, податків або інших відрахувань із джерел судноплавних компаній, добровільних внесків з боку судновласників, моряків та інших організацій [9].

Соціально - правове забезпечення моряків при портах повинно включати готелі або гуртожитки, придатні для тимчасового проживання моряків, якщо в них виникає потреба, які облаштовані належним чином та мають персонал, ціни у яких, повинні бути розумними та передбачена при необхідності можливість проживання в них сімей моряків. Також, при портах мають бути створенні з постійним вдосконалюванням підприємства соціально-побутового і культурного обслуговування, які повинні включати: приміщення для навчань, проведення зборів, консультацій і відпочинку, споруди для занять спортом та інші можливості для відпочинку поза приміщеннями, в тому числі для проведення змагань, якщо потрібно, умови для відправлення релігійного культу.

Моряки повинні бути ознайомлені з інформацією про ті служби, які існують для всіх працівників у портах заходу - особливо щодо транспорту, побутових і видовищних закладів, просвітницьких установ і про місця відправлення культу, а також про обслуговування, яке надається спеціально морякам. Таку інформацію, як правило моряки отримують на березі через брошури різними мовами, які обов'язково містять план міста і порту та через інформаційно - портові бюро. Моряків, які прибувають в порт, служби порту повинні в обов'язковому порядку проінформувати про будь-які види небезпеки і хвороби та, як їх уникнути, про необхідність своєчасно проходити лікування особам, які страждають на хвороби, і про найближчі 
служби, які проводять таке лікування, про небезпеку, спричинену вживанням наркотиків і алкоголю. У портах моряки повинні мати доступ до амбулаторного лікування хвороб і травм, до госпіталізації, в разі потреби, до зуболікарської допомоги, особливо в екстрених випадках. Державні органи порту інформують судновласників і моряків, котрі прибувають до порту, про будь-які особливі закони або звичаї даного порту, порушення яких може поставити під загрозу їхню свободу. При цьому кожний порт будь - якої країни повинен забезпечувати для моряків відповідне освітлення, позначення і регулярне патрулювання портових районів і під'їзних доріг.

Портові служби у разі потреби вживають заходи для захисту моряків від нападів та інших незаконних дій під час перебування судна на його території та в територіальних водах його держави і особливо на підходах до порту [10].

Портові служби повинні забезпечувати іноземних моряків доступом до їхніх консулів та сприяти ефективному співробітництву між консулами і місцевими або національними органами влади. У випадках, коли моряка затримують з якоїсь причини на території країни порту, то портові служби за його проханням, негайно повідомляють державу прапора і державу, громадянином якої $є$ моряк, яка повинна невідкладно повідомити найближчих родичів моряка. У разі арешту моряка державні органи судноплавства забезпечують надання консульським працівникам цих держав негайний доступ до моряка і можливість регулярно навідувати його до закінчення терміну його затримки. Справа затриманого моряка має розглядатися невідкладно відповідно до встановленої юридичної процедури, а держава прапора і держава, громадянином якої є затриманий моряк, повинні отримувати інформацію про хід справ. Моряки, які опинилися в іноземних портах у скрутному становищі, повинні отримувати всіляку практичну допомогу в очікуванні репатріації. Якщо репатріація моряків затримується, то відповідальна служба повинна негайно повідомити про це представника консульства або місцевого представника держави прапора.

Слід зазначити, що у відповідності зі сформованою міжнародною практикою прибережна держава не здійснює юрисдикції у справах, що належать до внутрішнього розпорядку на іноземному судні, включаючи цивільні спори між членами команди, що виникають у зв'язку з їхньою службою на суднах. Що стосується трудових правовідносин між членами екіпажу іноземного судна, то вони підпадають під юрисдикцію прибережної держави. Проте на практиці прибережні держави звичайно не втручаються в трудові спори між членами такого екіпажу, крім випадків, коли спір стосується заробітної плати або виконання обов'язків на борту судна, якщо інше не установлено відповідним договором. При цьому, слід пам'ятати, що цілий ряд соціально - правових заходів праці моряків регулюється конвенціями МОП і їхнє порушення в будь-якій країні, іноземному порту може спричинити втручання іноземних громадських організацій, насамперед національних профспілкових організацій. Подібні випадки мають місце у відношенні моряків українських суден, заарештованих в іноземних портах [11].

Адміністративна юрисдикція в основному базується на нормах адміністративного права, що встановлюють режим перебування іноземних 
суден у внутрішніх морських водах прибережної держави. Відповідно до цих норм іноземні судна, як державні, так і приватні, підлягають адміністративній юрисдикції прибережної держави в повному обсязі. Насамперед це стосується виконання митних і санітарних правил, а також заходів контролю, що належать до безпеки суден, охорони людського життя, допуску іноземців у портах

При цьому, на борту будь - якого судна моряки мають отримувати соціально-побутове обслуговування, яке включає в себе: перегляд телевізійних передач і прийом радіопередач, демонстрацію кінострічок або відеозаписів, запас яких має відповідати тривалості рейсу та, якщо потрібно, поновлюватися через регулярні проміжки часу, настільні ігри, палубні ігри, гімнастичні прилади, спортивне знаряддя, умови для занять плаванням, бібліотеку, яка містила б професійну та іншу літературу, запас книжок у якій має відповідати тривалості рейсу і поновлюватися через регулярні проміжки часу, умови для занять прикладним мистецтвом, програми професійної підготовки моряків, які повинні охоплювати навчання та інформування з питань, які стосуються їхнього побуту, в тому числі й загальних шкідливостей для здоров'я, доступ до телефонного зв'язку судна з берегом, вартість користування яких має бути доступною.

Відповідальні особи в порту та на борту судна повинні докладати всіх зусиль для того, щоб сприяти отриманню моряками звільнень на берег, по змозі, відразу після прибуття судна в порт. При цьому доцільно було б розробити міжнародні правила чи акти, щоб моряки могли отримували дозвіл на відвідування їхнього судна, що перебуває в порту, дружинами, родичами і друзями та при можливості дозволити дружинам моряків супроводжувати їх під час деяких рейсів. Такі дружини повинні бути охоплені належним страхуванням від нещасного випадку та на випадок захворювання судновласники мають надавати всіляку допомогу моряку в отриманні такого страхування [12].

Соціально-правове забезпечення крім належних умов праці, включає також умови проживання і роботи на борту від яких значно залежить підвищення рівня безпеки і охорони судноплавства, захист навколишнього середовища та привабливість роботи на морі. Судноплавство $є$ самою міжнародною із всіх великих світових галузей економіки і регулюється на міжнародному рівні, тому дуже велике значення придається розробці Конвенції МТС, яка охоплює майже всі трудові конвенції та вводить в дію нові міжнародні трудові стандарти. Україні потрібно теж ратифікувати дану конвенцію для приведення юридичної законодавчої' бази у відповідність з новими міжнародними умовами для важності трьохсторонньої кооперації між урядом, робітником та роботодавцем, так як Україна $є$ морською державою і повинна мати хороші традиції турботливого відношення до своїх працівників та розглядати своє морське законодавство в якості складового компоненту загального трудового законодавства, яке регламентує виконання робіт. Це обумовлюється і специфікою конкретного типу роботи і теми особливих умов в яких вона виконується. Забезпечення належного соціально - правового обслуговування неможливо представити без регламентуючих умов роботи на борту судна, які включають безпечні для здоров'я умови роботи, медичне обслуговування, норми (часи) роботи і 
відпочинку, захист в області соціального забезпечення моряків, право на репатріацію, щорічний оплатний відпочинок, справедливу винагорода за виконану роботу та інше. Соціальна допомога повинна включати також, психологічну та санаторну реабілітацію моряків і членів їхніх сімей, тому $є$ назрілим питання щодо створення центрів допомоги моряків у регіональних морських містах.

Невід'ємною частиною законодавчого процесу при цьому є оновлення національного законодавства в області морських трудових стандартів і приведення у відповідність з сучасними міжнародними і європейськими стандартами так, щоб вони могли відповідати сучасним розробкам і адекватно відображати нові умови. При цьому, діяльність по наданню послуг морякам повинна перевірятися та бути під строгим контролем компетентних органів, які відслідковують за кожним судном і завчасно попереджають судновласника про забезпечення належних умов на борту як того вимагає законодавство країни прапора судна та міжнародні акти. Конвенція МТC в даному напрямку надає глобальні стандарти щодо проживання і роботи на борту судна моряків, які використовуються на міжнародному рівні [5].

Судновласники при працевлаштуванні моряків поза межами їхньої держави повинні сприяти у збереженні їх грошових заощаджень та допомагати перераховувати заробітну плату їхнім сім'ям, організувавши просту, швидку і надійну систему, яка діяла б за сприяння з боку консулів або інших компетентних органів, капітанів суден, представників судновласників або надійних фінансових установ і давала б змогу морякам, зокрема тим із них, котрі перебувають у іншій країні або служать на судні, зареєстрованому в іншій країні, депонувати чи переказувати свою заробітну плату повністю або частково.

Згідно цього доцільно розширити межі фінансової системи, яка давала б змогу морякам у момент прибуття на судно або під час плавання переказувати, якщо вони цього бажають, частину своєї заробітної плати через регулярні проміжки часу своїм сім'ям, щоб ці перекази здійснювалися своєчасно і безпосередньо тій особі або тим особам, котрих зазначає моряк. Тому компетентні органи повинні докладати зусиль для забезпечення незалежного підтвердження фактичного переказу заробітної плати моряків зазначеній ним особі або особам [9].

Висновки. У проаналізованому законодавстві України містяться соціально-правові заходи у сферах медичного обслуговування, допомоги по хворобі, допомоги по безробіттю, допомоги по старості, допомоги у зв'язку з виробничим травматизмом, допомоги по інвалідності тобто ці механізми існують в Україні у належній кількості, але майже не діють, тому що потребують глобальних змін та удосконалень. При цьому потрібно удосконалити соціально - правове забезпечення моряків: при наймі їх на роботу - шляхом розробки програм стимуляції і збільшенням привабливості морської професії, створенням робочих груп по найму і професійним питанням у відношенні моряків, забезпеченням інформаційно - просвітницькими компаніями, розробкою дослідницьких проектів по вивченню довгострокових кар'єр на морі та інше, так як морська професія не може правильно функціонували без наявності усіх адекватних і підходящих соціальних умов. 


\section{СПИСОК ВИКОРИСТАНИХ ДЖЕРЕЛ}

1. Международный трудовой кодекс моряков. URL: http://aurora7. com.ua/index.php/2011-05-lT-13

2. Головина С.Ю. Правовое регулирование труда отдельных категорий работников. Правоведение. М., 2003. С.7.

3. Довжук О.В. Правове регулювання міжнародних приватних трудових відносин на сучасному етапі (матеріально-правовий аспект): Автореф. дис.канд.юрид.наук/ Київський національний університет імені Тараса Шевченка. К., 2006. URL: http://librar.org.ua/sectionsJoad.php?s=economy_ legal_

4. Горчаков С. Правове регулювання репатріації моряків. URL: http:// www.justinian.com. ua/article.php?id=991

5. Правовые аспекты репатриации моряков: Законодательство Украины и зарубежный опыт: Материалы Международной конференции: Море, судно, экипаж. 20-22 мая в Коктебеле (Украина). URL: http://www.maritimebusinessriews.com.ua/news/analytics_and_comments/2009/06/01/4028. html

6. Міжнародне морське право і Чорноморський регіон: матеріали семінару, 12-17 листопада 2001р., Одеса/ під редак. Є.В. Додіна: спец.випуск журналу «Митна справа»; ОНЮА, 2001. С.204.

7. Черниенко С.В. Личность и международное право. М, 1974. С.15

8. Правове регулювання трудової діяльності українських моряків. URL: http://otherreferats. allbest,ш/law/ 00130323_0.html

9. Працівники, як суб'єкти. Трудове право - Конспект лекцій http:// studentu-vuza.ru/trudovoe-pravo/konspekt-lektsiy/materialnaya-otvetstvennost-rabotnika.html.

10. Савич 0. С. Деякі питання соціального захисту моряків. Морське право: актуальні питання теорії та практики : Збірник наукових праць. О.: Іздат-Інформ ОНМА, 2010. Вип. 5. С. 116-121.

11. Беннет С. Чего должен ожидать ответственный судовладелец от ответственного государства флага? Материалы XIV Международного семинара: Качественное судоходство: стандарт XXI века. Человек и море: долгий путь к гармонии. 12-13 октября 2011 г. Санк - Петербург.

12. Бекяшев Д. К. Міжнародно-правове регулювання праці моряків: дисертація ... кандидата юридичних наук: 12,00.05, 12.00.10. Москва, 2001. $221 \mathrm{c}$.

\section{Pidpala}

\section{STRUCTURAL ELEMENTS OF THE SOCIAL AND LEGAL REGULATION OF SEAFARERS ‘LABOR}

Social protection is an integral part of human rights and requires special attention to the formation of social standards in the national and international maritime labor market. Today, radical economic transformations in Ukraine have sharply highlighted the problem of employment of workers in the merchant marine fleet. A significant reduction in the national fleet, the financial situation in the industry posed the problem of finding work in the world market for the sailors of 
Ukraine. Finding a job with a foreign shipowner-employer, a seaman "falls out" of the legal field of our state and becomes absolutely defenseless, both from the side of our state and from the side of the shipowner. There are no unambiguous statistical data on the quantitative composition of maritime labor migration, the number of Ukrainian seafarers working abroad is estimated at almost 60-100 thousand people. Lack of opportunities to apply their professional skills in Ukraine is not the only pressing problem for a seafarer. An important issue is the social protection of seafarers working abroad, both on the part of the ship owner-employer and the flag state, the state of jurisdiction and the state of citizenship. It has been found that shipowners, when employing seafarers outside their own country, should help to save their money and help transfer wages to their families by setting up a simple, fast and reliable system with the assistance of consuls or other competent authorities, shipowners, shipowners or sound financial institutions and would allow seafarers, in particular those who are in another country or serving on a ship registered in another country, to deposit or transfer their wages in whole or in part. It is determined that today the national legislation of Ukraine is outdated. This is primarily due to the medical legislation, which is in the post-Soviet system with ineffective mechanisms of free medical care and the absence of legislation in the field of compulsory health insurance. Medical legislation of Ukraine does not provide for special procedures for medical care of seafarers, and the existing mechanisms are ineffective.

Keywords: social protection, social and legal support, national legislation, seafarers' labor rights, international conventions. 